
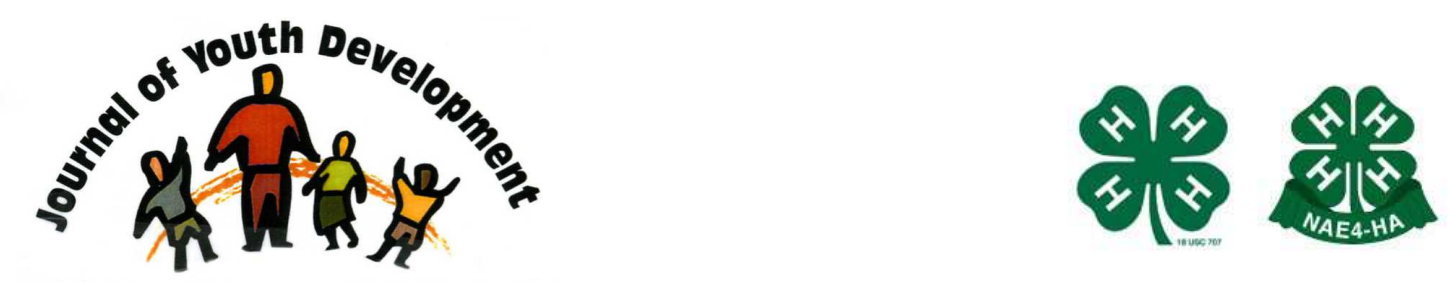

Bridging Research \& Practice

\title{
Working Toward Peace: A Holistic Approach to Addressing Youth Violence by Pleasant Hill Baptist Church
}

\author{
Joann E. Lee \\ Harvard University Extension School \\ Cambridge, MA \\ JoannL@gmail.com \\ Rev. Miniard Culpepper \\ Pleasant Hill Baptist Church \\ Dorchester, MA \\ pleasantchurch2@aol.com \\ Rhona Julien \\ Harvard University Extension School \\ Cambridge, MA \\ julibago@gmail.com
}




\title{
JOURNAL OF YOUTH DEVELOPMENT \\ bridging research and practice

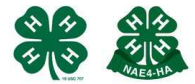

Volume 8, Number 2, Summer 2013

Article 130802PA003

\section{Working Toward Peace: A Holistic Approach to Addressing Youth Violence by Pleasant Hill Baptist Church}

\author{
Joann E. Lee and Rhona Julien \\ Harvard University Extension School \\ Rev. Miniard Culpepper \\ Pleasant Hill Baptist Church
}

\begin{abstract}
The prevalence of unintentional injury and violent behavior among school aged youth in Boston compared to the rest of the country is quite similar. And in the past decade, in spite of attempts both locally and nationally to stymie these behaviors, there has been no change in prevalence. Moreover, such behaviors are the leading cause of death and disability among youth and adults in the United States. This paper will discuss the strategies that have been employed by Pleasant Hill Baptist Church, Boston, MA in response to this trend and will focus on high-risk youth, especially those involved with gangs.
\end{abstract}

\section{Introduction}

Youth living in areas that are affected by violence and high rates of crime are more susceptible to engage in the types of behaviors that cause unintentional injuries and violence among youth (Ingoldsby, \& Shaw, 2002; Lansford, et al,. 2007). Moreover, studies show that youth who experience crime and violence are also more likely to have a sense of hopelessness about the future and increasing difficulty developing close relationships (Shakoor, \& Chalmers, 1991).

The psychological and emotional effects of witnessing violence reinforce a tendency towards committing those same violent behaviors (Green, \& Berkowitz, 1976; Lovaas, 1961; Osofsky, 1999; Margolin, \& Gordis, 2000). One of the main vehicles by which violence is perpetrated in these communities is through gang activity. Individuals involved in gangs often see their membership as the only thing close to family (Posick, et al., 2010). Given this worldview, the challenge is how to achieve positive and sustainable changes in the lives of youth who exist 
without the support of a traditional family structure and are faced daily with elusive norms and moral codes.

At the Pleasant Hill Baptist Church, a faith based organization in Boston, MA, senior pastor Reverend Miniard Culpepper believes true intervention requires 'meeting folks where they are.' In other words, change in the community begins one individual at a time. To do so, efforts should be void of preconceived notions, self-righteous dispositions and prejudice. Instead, we should create opportunities where sincere and meaningful relationships can take place.

African American clergymen first pioneered this approach to dealing with youth violence during a particularly troubling time in Boston. In 1990, gang violence contributed to 150 homicides, the majority of which occurred among youth aged 24 and less (Winship, 2002). Over the next decade, collaborative efforts between African American clergymen and police officers led to a dramatic decline in crime with just 31 homicides in 1999 (Winship, 2002). The violence was centered in the Dorchester, Roxbury and Mattapan neighborhoods, which are predominantly African American. After a particularly deadly incident at the funeral of a young homicide victim, the African American clergymen in the affected neighborhoods decided to take action and create a crisis response organization to address the city's gang-related crime and the related youth violence and homicides. They created the Boston TenPoint Coalition in 1992 and began streamlining the collective efforts of the community. The coalition ultimately brought together 67 churches, police officers and community organizations all aimed at reducing violence and minimizing gang activity among youth. Operation Ceasefire, their most well known campaign, employed a carrot and stick approach where gang members were convinced to quell their violent tendencies in exchange for education, services and jobs. This effort led to the dramatic decline in crime seen in 1999 and was coined the "Boston Miracle." The approach was hailed by then President Bill Clinton as a best practice to be replicated nationally.

However, combating youth violence, particularly that which is affiliated with gangs, is an ongoing process. A 2009 survey conducted in Grove Hall, a neighborhood in the Roxbury district of Boston, Massachusetts, reported that of the 1,050 troubled youth they had surveyed, 71 percent of males and 38 percent of females were on probation (Project RIGHT, et al., 2010). Seventy-two percent witnessed some gun violence in the prior year and "virtually everyone in the survey had a family member or friend who had been murdered" (Project RIGHT, et al., 2010). The youth surveyed also had a high prevalence for committing violence. Twenty five percent had used a gun to attack or threaten someone and 55 percent had physically fought with someone (Project RIGHT, et al., 2010).

Reverend Culpepper, whose Pleasant Hill Baptist Church (PHBC) is located in Dorchester, a neighborhood contiguous to Grove Hall, saw similar trends among area youth as early as 2006. PHBC is situated across the street from Trotter Park. The proximity of the park to PHBC reinforced the pastor's resolve to do something about the violence he witnessed among youth on a daily basis. He mirrored the positive efforts of the Boston TenPoint Coalition and adapted methods that had led to the earlier success of the Coalition. He and other clergy began walking the streets after school and at night. He befriended the youth and developed a relationship with them. A member of the steering committee responsible for the Grove Hall survey observed that individuals who experienced violence are "especially well suited to work with other disconnected youth to begin the process of re-engagement with community institutions, activities and educational resources (Project RIGHT, et al., 2010). For Reverend Culpepper, one young man from the Dorchester neighborhood adjacent to his church was the embodiment of this observation. 
This young man (hereinafter referred to as Adam) grew up during the heyday of the Boston Miracle. As such he was privy to a childhood that was minimally affected by the death and violence that were rampant prior to the Boston Miracle. Once he reached high school, he became acquainted with a few youth who were part of a neighborhood gang. And when he and the Reverend reunited in 2005, Adam was well on his way to becoming a leader. Shortly after their reunion, Adam was almost killed by a stray bullet and later jailed for carrying a gun in school. During his incarceration, he realized that the gang life, one of murder, assault and uncertainty were not for him. He wanted something different for himself and for those around him.

So as a charismatic and natural born leader, he began leading by example. When he got out of jail, he met regularly with Reverend Culpepper who eventually became his mentor. Adam was firmly on the path to resisting gang violence. As a leader, he participated in a monumental truce between his gang and a rivaling gang that fellow clergymen from the Boston TenPoint Coalition and law enforcement officers organized at the John F Kennedy Museum. The better life Adam was looking for, the one that advocated for peace instead of violence finally seemed like a reality. However four months later Adam was approached by two armed young men and subsequently shot to death.

In the precarious days that followed, Reverend Culpepper fasted for forty days and prayed. He resolved to continue the work he had begun with Adam and the neighborhood gang to create a Peace Plan for the community. This resolve manifested in the creation of the video, "Adam's Plan for Youth Peace" and a funded summer program designed to promote peace and prevent violence in the community. The Trotter Park Summer Peace Program was operational for its fourth consecutive year in 2012.

In the spring of 2012, funding was successfully secured to develop a year-round workforce development program based on a case management approach. This holistic approach consists of looking at the physical, emotional and psychological needs of the youth, especially those exposed to or who are victims of violence. Steady employment is one of a variety of measures that seeks to bring youth who experience violent crime and engage in risky behavior back on track to a more productive lifestyle. However, to reach this goal a number of issues must first be managed. These issues are found within the broad categories of mental health, legal, educational, and permanent housing (Posick, et al., 2010). The subsequent section will discuss the steps taken to evolve the program from the relationship with one youth to a program aimed at improving health outcomes in an entire community. It will then conclude with planning details to realize the workforce development program.

\section{Methodology}

In 2005, Reverend Culpepper was both the Regional Counsel for a federal agency and Pastor at PHBC. His keen experience as an arbiter of justice and a spiritual leader in the community propelled him to do something about the violence that was escalating right in the church's backyard. He began walking around the neighborhood surrounding the church, particularly in the vicinity of Trotter Park where the troubled population of youth aged 12-24 congregated after school and in the evenings. He remained alert, but easygoing. He made eye contact and exchanged smiles or head nods with those he passed. With his daily presence, he conveyed consistency. He put in time and let the neighborhood youth know that he was there to stay and 
that he was there to serve. However, his relationship with Adam was the key to unlocking the door with these youth.

Consistency opened the door to conversations. Once the youth saw him on his walks and saw that he was not going away, they allowed him to engage with them. He let it happen naturally and met them at their level. The youth wanted to be taken seriously and he did just that. He was non judgmental and with his mere presence, showed them there was another way to live.

Pastor Culpepper's interactions with Adam began when Adam was very young and continued to be a relationship that was built around consistency and conversation. The two exchanged ideas on what was fundamentally necessary for peace to happen in the neighborhood and it was from these conversations that the following six-point plan to peace emerged.

\section{Adam's Six Point Peace Plan}

1. Withdraw: Do not enter other gang territories with the intent to cause mischief.

2. Resources: Pursue employment opportunities by taking advantage of the tools in the community, such as those services provided by community organizations, counselors and job centers.

3. Rebuild: Improve one's life by focusing on the pillars of spirituality, employment, leadership and concentrating on developing a future.

4. Responsibility: Take care of one's outstanding legal issues.

5. Autonomy: By becoming unaffiliated with gang life, one can gain the freedom to travel to any part of the city without fear of retaliation by rival gangs.

6. Sector Meetings: Participate in open dialogue with rival gang members about ongoing issues in the area.

In 2006, just a year after the reunion with Adam, a momentous truce between rivaling gangs was achieved. Reverend Culpepper worked with Adam and his gang to get them prepared to accept a truce thereby bringing peace to their community. The Boston TenPoint Coalition worked with the rival gang and the Boston police to get both gangs to the negotiating table. Police officers provided additional resources and incentives to achieve the truce. These efforts culminated on July 24, 2006 with a truce that would end violence in both their neighborhoods.

The truce was broken four months later when Adam met his untimely death. During this volatile time, Reverend Culpepper appealed to those impacted to focus on promoting peace. The threepronged outreach included the youth who helped author the Peace Plan, the youth who were not involved in the Peace Plan but had attended church with Adam and the families of the youth who frequented the area. He asked them to take the anger they felt and put it towards a constructive task, the task of telling the story of Adam. A videographer was brought in to teach the youth the skills they would need and they took it from there. The result was a well-edited video, entitled Adam's Plan for Youth Peace that laid out the six point peace plan and told the story of Adam and his quest for peace.

However, Reverend Culpepper knew that it was not enough to just tell the story. He began searching for ways to provide a program that would address the needs of the community and engage the youth in positive activities. The result was the Trotter Park Summer Peace Program that began in 2009. The program, from inception to execution, was conducted according to the following four steps:

(1) determine the need, 
(2) gather the resources,

(3) plan the engagement and

(4) execute the program.

\section{Determine the need}

Between 2007 and 2009, Reverend Culpepper engaged with the youth of the Humboldt Street neighborhood in many ways. While work on the video continued, the pastor and youth took part in roundtable discussions about how to best address theirs and the overall community issues, one on one conversations and counseling. These activities illuminated the fact that there was a need for community unification, healthy activities and a wealth of support sessions that helped youth deal with their various issues. Using this feedback, Reverend Culpepper began looking for the resources to further advance the strides made in promoting peace in the community.

\section{Gather the resources}

Reverend Culpepper looked toward his congregation to play an active role in providing the resources necessary to further peace in the neighborhood and community at large. During an open meeting at the church one evening, he spoke about the work he had done with the youth in the area and described the needs that still existed. He called on members in attendance to volunteer their skills and time toward this worthy cause. Moved by the work of the Reverend with the youth in the area, several members volunteered their time and expertise to support and promote Reverend Culpepper's efforts to further peace. This core team of volunteers included a grant writer and researcher, a retired police officer and several youth engagement professionals experienced in arts, media and athletics. Together, they laid the framework for a volunteer led program (Program) that would serve the youth of the neighborhood.

Additional resources available for the Program included ongoing relations with other faith-based organizations (FBOs). These included Greater Love Tabernacle, Strong Tower and Bethel Baptist Church among others. The Teen Empowerment and Urban Youth Leadership Corp assisted with creative arts programming. Other professional development and community-based organizations such as the Boston Neighborhood Network, Roxbury YMCA, Roxbury Boys and Girls Club and Ecumenical Social Action Committee (ESAC) served as resources and referral sources for the Program. Aside from these organizations, the Trotter Park and PHBC provided physical resources for the Program and served as host sites for many events. Trotter Park was particularly important because it provided green and open space for family activities and recreation.

\section{Plan the Engagement}

PHBC successfully obtained funding from the American Baptist Churches of America, Black Ministerial Alliance (BMA) and the Boston Foundation because of compatible goals to provide safe and healthy programs for Boston youth. Based on the available funding and the need for activities that the Reverend and youth had identified, the group developed a summer program that would include support sessions such as leadership workshops, a career and resource fair and a teen café activity that would feature occasional guest speakers. Recreational activities would include a basketball league, video games, karaoke, open mic nights, board games, pingpong, hula-hoop and jump rope. And community gatherings would include movie nights, cookouts and a kick-off and close-out event to mark the beginning and end of the program and provide an opportunity where the entire neighborhood could participate and celebrate. The activities typically occur during an eight-week period in the summer. A sample schedule of workshops and Program activities are listed in Table 1. 
Table 1

Program Activities

\begin{tabular}{|c|c|c|c|c|c|}
\hline Week & Mon & Wed & Thu & Fri & Other \\
\hline Week 1 & & & & & $\begin{array}{l}\text { Kick-off event } \\
\text { (1st Sat in } \\
\text { July)) }\end{array}$ \\
\hline Week 2 & Karate Workshop & $\begin{array}{l}\text { Video Making } \\
\text { Workshop }\end{array}$ & $\begin{array}{l}\text { Teen Café } \\
\text { (TC) } \\
\text { Karaoke }\end{array}$ & Movie Night & \\
\hline Week 3 & $\begin{array}{l}\text { Conflict Resolution } \\
\text { Workshop }\end{array}$ & $\begin{array}{l}\text { Makings of an } \\
\text { Athlete } \\
\text { Presentation }\end{array}$ & $\begin{array}{l}\text { TC-board } \\
\text { games, wii }\end{array}$ & Movie Night & \\
\hline Week 4 & $\begin{array}{l}\text { Step } \\
\text { Demonstration }\end{array}$ & $\begin{array}{l}\text { 1. Life as a } \\
\text { Journalist } \\
\text { 2. Healthy } \\
\text { Relationships - } \\
\text { Teen Dating and } \\
\text { Violence }\end{array}$ & $\begin{array}{l}\text { Teen Café } \\
\text { (TC) - open } \\
\text { mic }\end{array}$ & Movie Night & \\
\hline Week 5 & $\begin{array}{l}\text { Job Readiness } \\
\text { Training - } \\
\text { Effective } \\
\text { Communication }\end{array}$ & Peace Promotion & $\begin{array}{l}\text { TC) - Guest } \\
\text { Spkr. }\end{array}$ & Movie Night & \\
\hline Week 6 & $\begin{array}{l}\text { Basketball \& ping } \\
\text { pong night }\end{array}$ & $\begin{array}{l}\text { Teen } \\
\text { Empowerment }\end{array}$ & $\begin{array}{l}\text { TC }- \text { board } \\
\text { games, ping } \\
\text { pong }\end{array}$ & Movie Night & \\
\hline Week 7 & Acting 101 & Job/Career Fair & $\begin{array}{l}\text { TC - board } \\
\text { games, wii }\end{array}$ & Movie Night & \\
\hline Week 8 & $\begin{array}{l}\text { Life skills } \\
\text { workshop }\end{array}$ & $\begin{array}{l}\text { Overcoming } \\
\text { adversity } \\
\text { workshop }\end{array}$ & $\begin{array}{l}\text { TC }- \text { board } \\
\text { games, ping } \\
\text { pong. }\end{array}$ & Movie Night & $\begin{array}{l}\text { Basketball } \\
\text { League Kick-off } \\
\text { (Last Sat in } \\
\text { Aug.) }\end{array}$ \\
\hline
\end{tabular}

The organizational structure for the Program was based on the capacity of volunteers to oversee the different functions. The main officers for the Program consisted of a Program Director, Workshop Coordinator, Career Resource Fair and Youth Activity Coordinator, Youth Outreach Leaders, Park Security Officers and Food Coordinators.

The Program Director develops the overall strategy for the Program, manages staff and oversees the implementation of structured activities such as workshops, career resource fair and the basketball league and unstructured activities such as movie nights, BBQ and cookouts. The Workshop Coordinator develops the strategic direction and coordination of the workshops. The Career Resource Fair and Youth Activity Coordinator is responsible for the coordination of the career resource fair as well as providing direct supervision to the youth who assist with preparing workshop activities and events. The Youth Outreach Leaders are responsible for promoting the summer activities in Trotter Park and for recruiting other community youth to participate in the workshops and career fair. They are also responsible for the setup and breakdown of displays and other equipment and structures used during the Program activities. The Park Security Officers are responsible for promoting and securing a safe environment in the Park including park perimeter and areas surrounding Pleasant Hill Baptist Church. The Food Coordinators are responsible for purchasing and preparing healthy meals for the participants of the Program. The positions of Youth Outreach Leaders and Park Security Officers are reserved for youth that frequent Trotter Park so that they can gain experience as a member of the 
workforce from the safety and familiarity of the Program structure. A schematic of the Summer Peace Program staffing is provided in Figure 1.

Figure1

Organizational Chart for Trotter Park Summer Peace Program

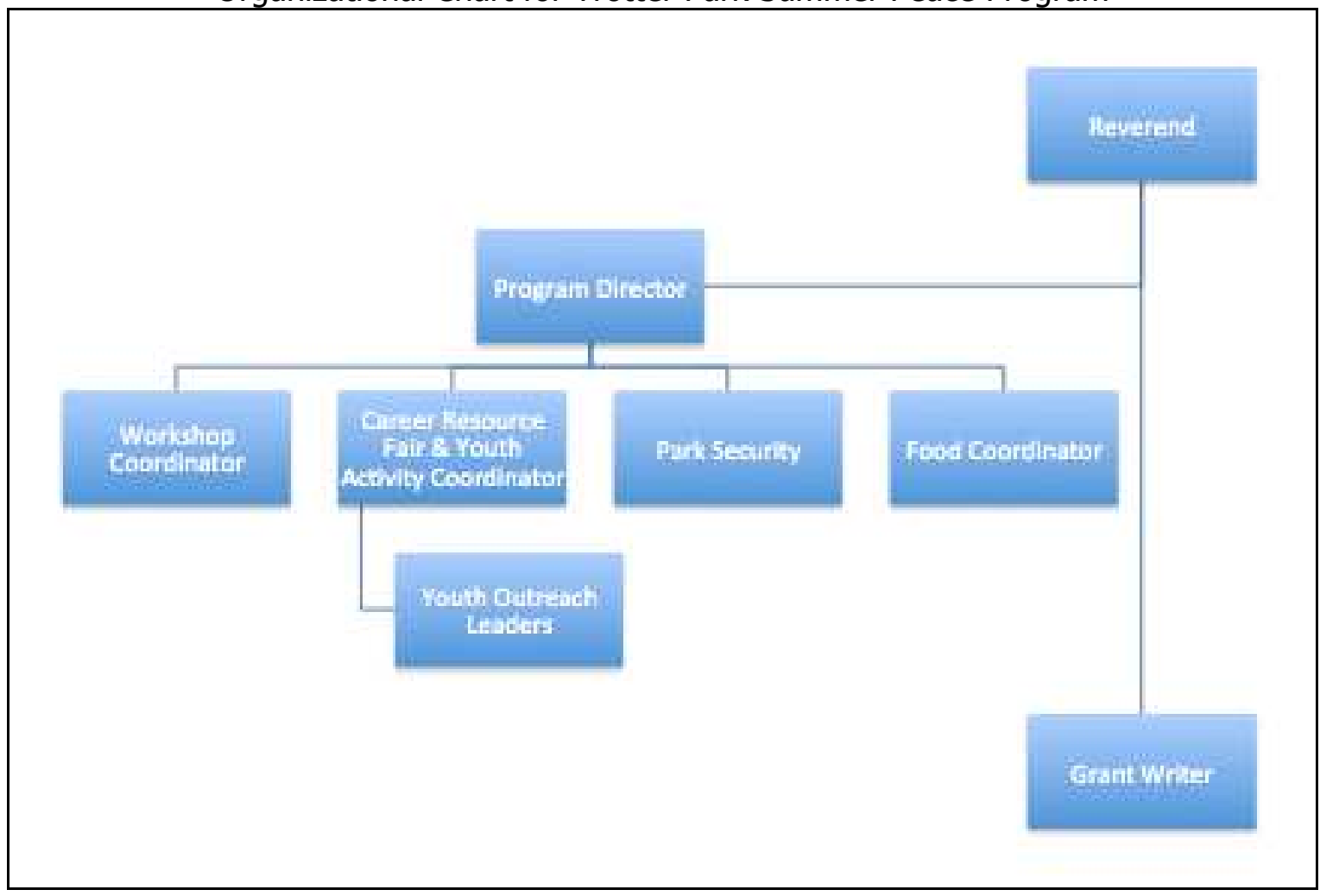

\section{Execute the Program}

The Planning Committee (Committee) meets on a weekly basis for two months prior to the eight-week summer Program. They use this time to coordinate the details of the events, interview the youth and young adult candidates for the positions of Youth Outreach Leaders and Park Security and market the Program to the community. Outreach about the Program and position listings are done via flyers distributed throughout the neighborhood, church announcements, community bulletins and 'word of mouth.'

In its inaugural year, the program had over 500 participants including both kick-off and closeout events. From the very beginning, the program was warmly received by the community because of the efforts to promote community solidarity, provide entertainment and employ the youth and young adults. One Friday evening during the inaugural 2009 Summer Peace Program, a young man approached Reverend Culpepper and said "Hey Rev, I just got out. I need one of these jobs." He was referring to the Park Security positions that were available to the at risk youth during the summer program. That year four court-involved youth were hired as Park Security Officers to focus on non-violence and peace during the hours the Program was operational. Not only were these young people heavily involved in maintaining "good order" and "peace," they took their security responsibility very seriously. They reported to work on time every day of the Program. There were no re-arrests or incidents at the Trotter Park during the entire summer. Further, the youth were able to report to their probation officers that they were employed. Their participation in the Program was evidence that court-involved youth are capable of making positive changes in their lives if given the opportunity. In 2011, three 
additional park stewards were hired. These youth have made great progress in maintaining peace in their community.

Now in its fourth year, the Trotter Park and Humboldt Street neighborhoods are well aware that this is their Program and they look forward to participating in it. In fact it is not unusual to be approached by long time residents inquiring about the start date of the Program or to receive favorable comments from outstanding community residents.

\section{Program Evolution}

Metrics were developed between 2009 and 2012 to determine successful outcomes of the program. These included the number of participants attending the workshops and various other events and anecdotal evidence garnered from feedback from program attendees. As stated earlier, the Program's success was achieved by engaging youth and community members in structured and recreational activities such as workshops, presentations, cook-outs and movie nights and providing healthy meals weekly. There was also an opportunity for employment that gave youth, particularly court-involved youth, a chance to hold a job and gain experience as a member of the workforce. The Program thus far has engaged the youth in activities that keep them off the street and employed.

In its fourth year, the community youth who staffed the Program were gaining the exposure needed to help them develop personally and professionally. They understood the importance and value of having the Program in their community and made great strides to ensure that its future was not jeopardized. They avoided risky behaviors, served as role models to other youth in the community, sought permanent jobs or job training and in some instances, looked into obtaining their GED or High School Equivalency diploma. In fact, over the past 4 years that the Program has been in existence, of the 15 plus youth that were hired each summer, there has only been one re-arrest. This is an outcome that the Pastor attributes to the engagement of the community youth in the Program and subsequent awareness of a more positive and productive lifestyle.

The pastor has built off of this success and has since acquired additional funding to secure a career development and job placement coordinator. This individual would focus on engaging youth in a case management program that would not only focus on job placement, but all the aspects of their lives, including health, education, legal matters and any other aspect of their lives requiring intervention. The Coordinator was therefore responsible for building a trusting relationship with the youth through consistency and the conversation approach first implemented by Reverend Culpepper several years ago and which has been the working culture of the Summer Program staff. Once a relationship with the youth was established the Coordinator would then engage the youth in the job placement process by having them fill out an intake form to understand the skills, knowledge and other aspects of their lives that might be hindering their education or employment goals. The coordinator would manage these aspects of their lives, referring them to resources and outside providers when necessary.

In order to strategically map out and execute this year round program, the Committee partnered with the Black Ministerial Alliance to engage in a process management system for the Program using a logic model. A logic model allows an organization to understand how desired outcomes are achieved by looking at its resources and activities (Yampolskaya, et al., 2004). Thus with funding and technical assistance from BMA, the Committee developed a logic model for their community youth program (Figure 2). This process consisted of agreeing on who was the target population for the year round program, identifying all the resources available to the Church to build this program, listing all the activities that would occur during the summer and creating an infrastructure to provide year-round service to community youth. 
Figure 2

Logic Model for Pleasant Hill Baptist Church Youth Program

Input

- Core Program Team

- Funding

- Partnerships w/ education, youth, health \& legal orgs

- External training

- Mentors

- Volunteers

-Workshop Presenters

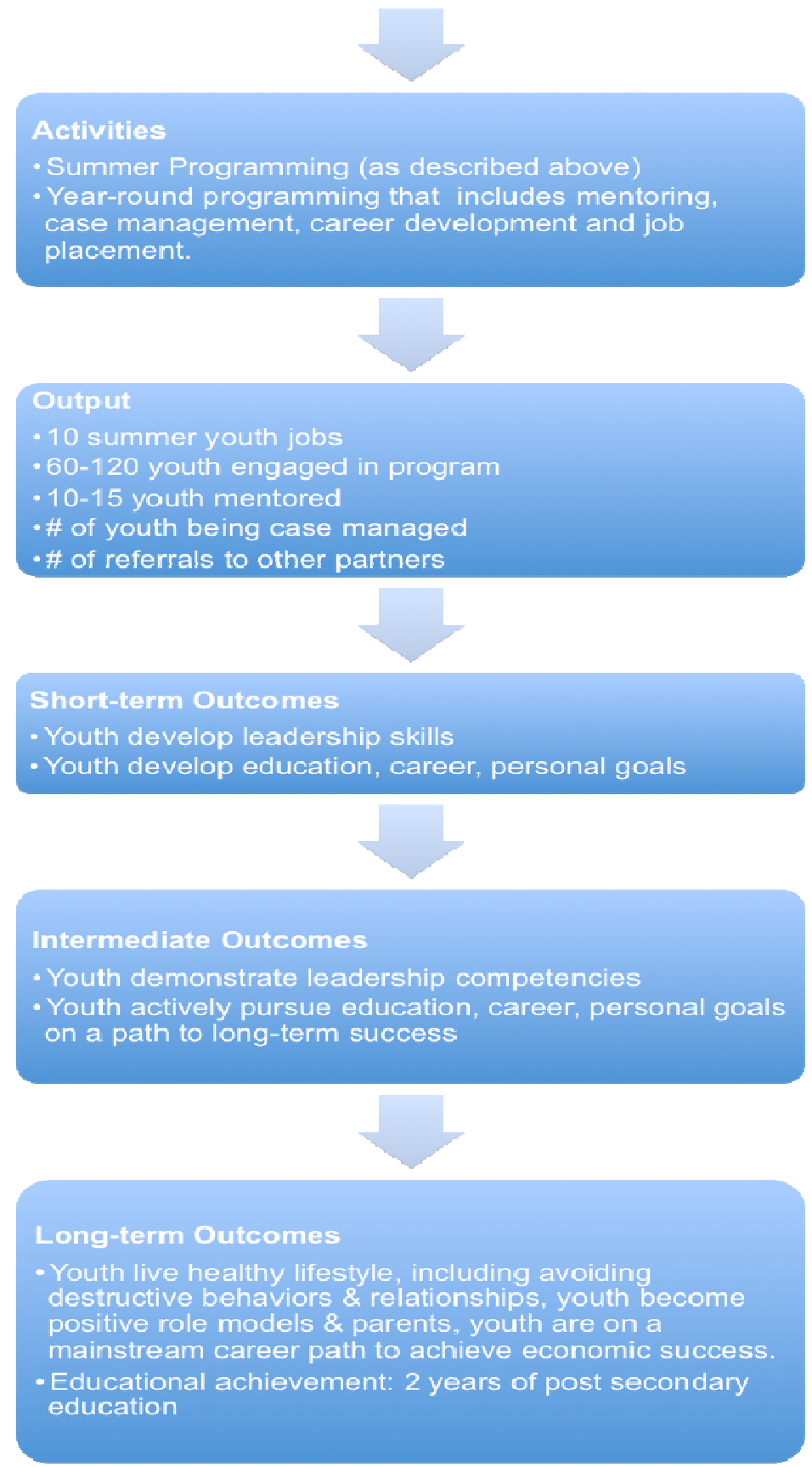


Building the logic model took over eight weeks in the spring with one to two hour weekly meetings with Committee members. These meetings also included two training sessions for committee members to gain a better understanding of the model and its utility. Although the Committee wanted to help as many program participants as possible, in the end, they decided an incremental approach was most effective and targeted youth ages 12-18 for their pilot. They felt this age group provided a critical opportunity for intervention coupled with the fact that these youth were most at risk. An additional component of the yearlong program was the mentoring aspect. Providing successful mentors that are available to youth on a weekly basis helps them psychologically as these relationships foster feelings of security, hope and responsibility.

\section{Conclusion}

At this time, efforts are underway to develop a yearlong program with the inclusion of case management and mentoring opportunities. These additional components have the potential to improve the impact of this Program as it will engage youth in providing greater input on planning the strategic direction of the Program and the services that will most help them achieve long-term education and employment goals.

While our program may not be unique, the leadership of $\mathrm{PHBC}$ has recognized the fact that young people know young people best. Indeed, it is the collective wisdom of the team, both old and young alike that has brought us to this point. As we build upon the successes of our summer program, we do so acknowledging that our youth must be at the table. We are setting our sights on playing a major role in the field of youth development starting with the youth in our community. Finally, we will always be indebted to the young man from Roxbury who sacrificed his life so that others may live in peace. May he Rest In Peace (RIP).

\section{Acknowledgments:}

The Boston TenPoint Coalition was founded in 1992 by Reverend Eugene Rivers, et al., as an answer to escalating youth violence and death due to gangs. It is "an ecumenical group of Christian clergy and lay leaders working to mobilize the community around issues affecting Black and Latino youth". To learn more about the important work of the Boston TenPoint Coalition, visit http://www.bostontenpoint.org

An acknowledgment of the many people and organizations who have made the Trotter Park Peace Program possible must begin with our funders. These include the American Baptist Churches of America, Black Ministerial Alliance and The Boston Foundation.

We are equally indebted to the Program Staff and Volunteers who dedicated countless hours in the planning and execution of the Program. It would not be what it is today without your efforts. We also owe a debt of gratitude to the $\mathrm{H}$ Street community and youth. Your acceptance, encouragement and participation in the Program continue to shape it into what it is today. Very special thanks to the congregation of Pleasant Hill Baptist Church. Your prayers give us strength to continue this important work in our church's backyard.

\section{References}

Green, R.G., Berkowitz L. (1976). Some conditions facilitating the occurrence of aggression after the observation of violence. Journal of Personality. 35(4):666-676. 
Ingoldsby,E.M., Shaw, D.S. (2002). Neighborhood contextual factors and early-starting antisocial pathways. Clinical Child and Family Psychology Rev. 5(1):21-55.

Lansford, J.E., Miller-Johnson, S., Berlin, L.J., Dodge, K.A., Bates, J.E., \& Pettit, G.S. (2007). Early physical abuse and later violent delinquency: A prospective longitudinal study. Child Maltreatment, 12(3), 233-245.

Lovaas, O.I. (1961). Effect of exposure to symbolic aggression on aggressive behavior. Child Development. 32(1):37-44.

Margolin, G., \& Gordis, E.B. (2000). The effects of family and community violence on children. Annual Review of Psychology. 51(1):445-479.

Osofsky, J.D. (1999). The impact of violence on children. The Future of Children. 9(3): 33-49. Retrieved from http://www.jstor.org/stable/1602780.

Posick, C., Wolf, R., McDevitt, J., Germain, M., \& Stark, J. (2010). Preparing at-risk and ganginvolved youth for the workforce: an analysis of promising programmatic strategies from local and national youth employment programs. A Resource Guide for the Shannon Community Safety Index.

Project RIGHT, Boston TENPOINT Coalition, Health Resources in Action, Harvard Youth Violence Prevention Center. (2010). Connecting the disconnected: a survey of youth and young adults in Grove Hall.

Shakoor, B., \& Chalmers, D. (1991). Co-victimization of African American children who witness violence: effects on cognitive, emotional and behavioral development. Journal of the National Medical Association, 83(3), 233.

Winship, C. (2002). End of a miracle? crime, faith and partnership in Boston in the 1990s. Cambridge, MA: Harvard University.

Yampolskaya, S., Nesman, T.M., Hernandez, M., \& Koch, D. (2004). Using concept mapping to develop a logic model and articulate a program theory: a case example. American Journal of Evaluation. 25(2):191-207.

(C) Copyright of Journal of Youth Development $~$ Bridging Research and Practice. Content may not be copied or emailed to multiple sites or posted to a listserv without copyright holder's express written permission. Contact Editor at: patricia.dawson@oregonstate.edu for details. However, users may print, download or email articles for individual use.

ISSN 2325-4009 (Print); ISSN 2325-4017 (Online) 